Article

\title{
The Role of Winter Rain in the Glacial System on Svalbard
}

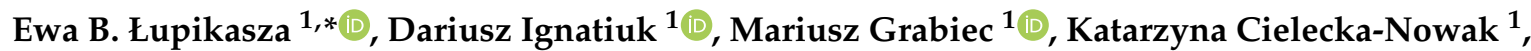
Michał Laska ${ }^{1}{ }^{(D}$, Jacek Jania ${ }^{1}$, Bartłomiej Luks ${ }^{2} \mathbb{D}$, Aleksander Uszczyk ${ }^{1}$ and Tomasz Budzik ${ }^{1}$

1 Faculty of Earth Sciences, University of Silesia in Katowice, Będzińska 60, 41-200 Sosnowiec, Poland; dariusz.ignatiuk@us.edu.pl (D.I.); mariusz.grabiec@us.edu.pl (M.G.);

katarzyna.cielecka1@gmail.com (K.C.-N.); michal.laska@us.edu.pl (M.L.); jacek.jania@us.edu.pl (J.J.);

aleksanderuszczyk@gmail.com (A.U.); tomasz.budzik@us.edu.pl (T.B.)

2 Institute of Geophysics, Polish Academy of Sciences, Księcia Janusza 64, 01-452 Warsaw, Poland; luks@igf.edu.pl

* Correspondence: ewa.lupikasza@us.edu.pl; Tel.: +48-503-086-072

Received: 2 December 2018; Accepted: 10 February 2019; Published: 15 February 2019

\begin{abstract}
Rapid Arctic warming results in increased winter rain frequencies, which may impact glacial systems. In this paper, we discuss climatology and precipitation form trends, followed by examining the influence of winter rainfall (Oct-May) on both the mass balance and dynamics of Hansbreen (Svalbard). We used data from the Hornsund meteorological station (01003 WMO), in addition to the original meteorological and glaciological data from three measurement points on Hansbreen. Precipitation phases were identified based on records of weather phenomena and used-along with information on lapse rate-to estimate the occurrence and altitudinal extent of winter rainfall over the glacier. We found an increase in the frequency of winter rain in Hornsund, and that these events impact both glacier mass balance and glacier dynamics. However, the latter varied depending on the degree of snow cover and drainage systems development. In early winter, given the initial, thin snow cover and an inefficient drainage system, rainfall increased glacier velocity. Full-season winter rainfall on well-developed snow was effectively stored in the glacier, contributing on average to $9 \%$ of the winter accumulation.
\end{abstract}

Keywords: precipitation; winter rain; mass balance; Hansbreen; glacier dynamics; Arctic; rain-on-snow

\section{Introduction}

Water circulation within a glacier's body governs numerous glacial processes, including mass and material transport, dynamics, and thermal state [1-4]. The main sources of fresh water available to glaciers originate from liquid precipitation, surficial, englacial, and subglacial melting, or water flowing from unglaciated areas [5,6]. Water delivered to the glacier may be retained in various phases (liquid or solid) and on various timescales, then released with a specific time lag [3]. According to studies in Svalbard catchments, rainwater constitutes 5.6\% of the total runoff from Kongsfjorden basin [7], and $17-28 \%$ of the runoff from Werenskioldbreen catchment [8]. Due to the precipitation type's dependence on air temperature, the contribution of rainfall to precipitation is highest in summer and lowest in winter. Summer rainfall is more frequent; thus its significance for glacier mass balance, dynamics, surface energy balance, water drainage system, and other glacial processes has been widely acknowledged, e.g., [9-11]. An increase in winter rainfall has been observed recently, suggesting that this phenomenon can be expected to be more common in the future due to climate warming $[8,12,13]$. Consequently, the importance of rainwater in glacial processes during cold seasons will increase. 
This imposes the need to learn how winter rainwater influences glacial processes, as opposed to summer, an issue that is currently poorly understood. Winter rainfall should be classified as a mass gain for the glacier, one which is retained at least temporarily within the glacier's body [3]. In early winter, when snow cover has not yet developed, rainwater is rapidly drained into the englacial system or firn aquifer. This water exerts a considerable influence on both the glacier's hydroglaciological system and dynamic behavior.

Later, during the snowy phase of winter, rainfall can freeze on the supercooled snow surface or beneath it, creating Ice Formation (IF) layers [14]. IF, along with melt-freeze crusts (MFcr), generate structures of greater density $\left(>500 \mathrm{~kg} \mathrm{~m}^{-3}\right)$, and lower permeability compared to percolating meltwater, leading to increased thermal conductivity [15]. The presence of ice crusts in the snowpack influences numerous glacial processes, e.g., surface erosion, ablation, and percolation rates, retention capacity, and heat fluxes [15]. Winter rainwater stored in surficial glacier layers contributes to refreezing, which is controlled by cold content and cold wave penetration depth [11]. The fusion latent heat released during this process may considerably modify glacier thermal properties, thereby contributing to formation and duration of temperate layers [16].

This study bridges the gap in existing knowledge on the significance of winter rain in glacier dynamics, its mass balance, and snowpack structure of the Arctic glacial system using Hansbreen (southern Spitsbergen) as an example for the period 2009-16. The paper assesses the contribution of rainfall to winter mass balance, and investigates the dynamic response of the glacier to rainfall in the cold season (Oct-May). The climatology of precipitation phases and trends in winter rainfall in Hornsund are also discussed as a background for further analysis. In the following parts of the paper, terms "liquid precipitation" and "rainfall" are used in the context of the entire year and winter, respectively; while "rainwater" is used in the context of glaciers.

\section{Study Area}

We studied the role of winter rainwater in Hansbreen's glacial system (Figure 1), a tidewater glacier in South Spitsbergen (Svalbard). This medium-sized $\left(54 \mathrm{~km}^{2}\right.$, [17]) and gently sloping (median surface inclination $26^{\circ},[18]$ ) outlet glacier can be considered as a representative of the entire region. The main tongue, characterized by a general N-S orientation, calves into the Hornsund fjord along a front ca $1.5 \mathrm{~km}$ wide. Four large tributary glaciers (Fuglebreen, Tuvbreen, Deileggbreen, and Staszelisen) reach the main stream from the western side, while several small steep ice bodies can be found on its eastern side. The glacier's vertical range is over $500 \mathrm{~m}$, resulting in wide variations in air temperature and precipitation.

The Hansbreen valley is surrounded by relatively high mountain ranges characterized by N-S orientation. Sofiekammen, a compact ridge elevated up to $500 \mathrm{~m}$ above the glacier's surface, constitutes its eastern boundary [18]. The glacier's western side is limited by a less uniform group of massifs (Fugleberget, Skoddefjellet, Skalfjellet, Deilegga, Slyngfjellet, and Strypegga), divided by narrow cols, connecting Hansbreen with neighbouring Werenskioldbreen. Wide passes in N and NE parts of the glacier connect Hansbreen to a contiguous glacier system comprising Vestre Torellbreen (Vrangpeisbreen) and Paierlbreen (Kvitungisen). Mountain ridges surrounding Hansbreen constitute effective orographic barriers influencing the glacier's topoclimatic conditions.

The glacier's valley orientation induces NW (in the northern part) and N (in central part) winds, which are not very strong, although they occur with the greatest frequency $[19,20]$. The second most frequent wind direction is E [19], resulting from the macroscale eastern circulation [21]. The average wind speed at an altitude of ca $187 \mathrm{~m}$ above sea level (a.s.l.) (H4) (Figure 1) in the winter seasons 2010/2011-2013/2014 ranged from 3.5 to $4.7 \mathrm{~m} \mathrm{~s}^{-1}$ [20]. The western ridges bordering Hansbreen block advection of mild and humid air from the $\mathrm{S}$ and $\mathrm{W}$ sectors, thus forming orographic precipitation that frequently drifts over the ridge; therefore the leeward side of the barrier, where the wind force is reduced, favours snow deposition during winter [20]. This phenomenon is responsible for the annually recurring asymmetric pattern of snow distribution on the glacier, characterized by preferential 
accumulation in the western sector of Hansbreen [19,20,22,23]. Winter air temperatures over Hansbreen are strongly determined by altitude. The most frequent below-freezing-point conditions are interrupted by several thaw periods [20]. Rain-on-snow events, frequently co-occurring with warm spells in winter, are recorded in the Hansbreen snowpack structure as ice formations [15,24,25].

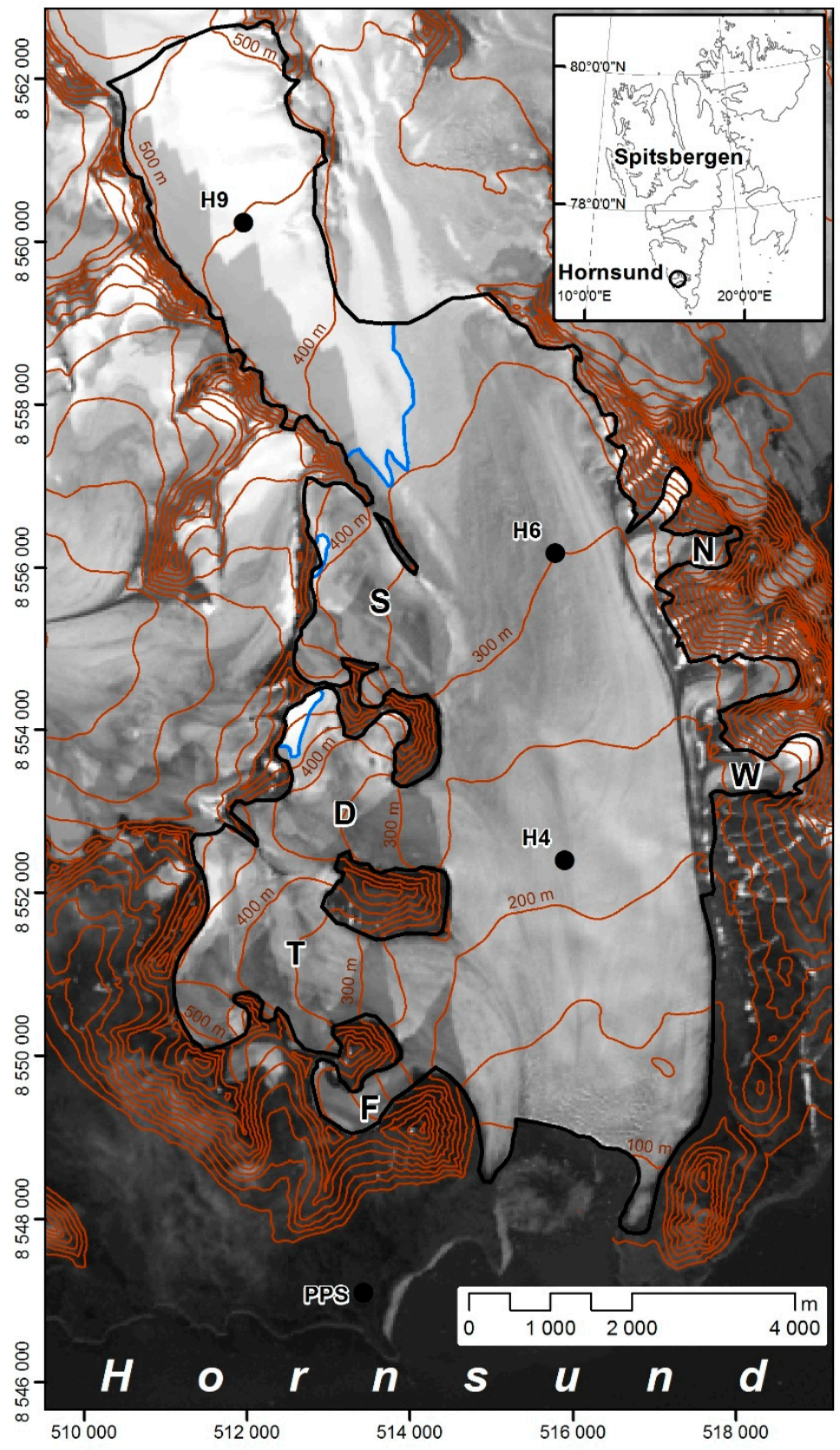

Figure 1. Study area and location of the meteorological station at the Polish Polar Station Hornsund (PPS) and automatic weather stations and mass balance stakes on Hansbreen (H4, H6, H9) on the background of LandSat on 26.09.2015. Blue line, snow line on 26.09.2016; capital letters, tributary glaciers: D, Deileggbreen; F, Fuglebreen; N, Nordstebreen; S, Staszelisen; T, Tuvbreen; and $\mathrm{W}$, Wienerbreen.

The long-term (1989-2011) average winter accumulation of $0.97 \mathrm{~m}$ w.e. (water equivalent) is insufficient to compensate for mass loss due to surface ablation ( $-1.26 \mathrm{~m}$ w.e.), resulting in a negative net surface balance of $-0.28 \mathrm{~m}$ w.e. [18]. The average altitude of the equilibrium line is $370 \mathrm{~m}$ a.s.l. (varying between 316-427 $\mathrm{m}$ a.s.l. over the studied period), deviating towards lower elevations 
on the western side of Hansbreen and depending on the asymmetry of the snow depth field [18]. Glacier dynamics vary in terms of space and time. Surface velocity increases towards the calving front, from 55-70 $\mathrm{m}_{\text {year }}{ }^{-1}$ near stake H4 [26] to over $230 \mathrm{~m} \mathrm{year}^{-1}$ at the front in late summer 2009 [18]. Speed-up events are observed during episodes of liquid precipitation or intense surface ablation [27].

\section{Materials and Methods}

The data used in this study were derived from the meteorological station (WMO No 01003, $77^{\circ} 00^{\prime} \mathrm{N}, 15^{\circ} 33^{\prime} \mathrm{E}, 10 \mathrm{~m}$ a.s.l) at the Polish Polar Station Hornsund (PPS), and from three automatic weather stations (AWSs) located in various glacial zones of Hansbreen: H4 (ablation zone, ca $187 \mathrm{~m}$ a.s.l), H6 (near the equilibrium-line altitude ELA, ca $278 \mathrm{~m}$ a.s.l.), and H9 (accumulation zone, ca $424 \mathrm{~m}$ a.s.l.) (Figure 1). PPS is located on the northern shore of the Hornsund fjord, around $4 \mathrm{~km}$ east of its mouth, and $3 \mathrm{~km}$ from the Hansbreen terminus. In addition to AWSs, each measurement point (H4, H6, and H9) was equipped with an ablation stake. A DGPS (Differential Global Positioning System) receiver was installed close to $\mathrm{H} 4$ for surface velocity measurements. The static survey was done automatically every $3 \mathrm{~h}$ during the $30 \mathrm{~min}$ sessions. Measurements of stake displacement with the GPS antenna had an average accuracy better than $10 \%$. Unfortunately, the measurement series was not complete due to power supply shortage during polar nights and other technical problems resulting from severe winter conditions. Despite such difficulties, several speed up events related to the rainfall occurrence phenomena have been documented.

Data of a sub-daily resolution on precipitation (12-h totals measured at 06 and 18 UTC), air temperature (every $3 \mathrm{~h}$ starting at $00 \mathrm{UTC}$ ), snow cover, and weather phenomena (every $3 \mathrm{~h}$ starting at 00 UTC) covering the July 1978-June 2000 period were taken from Hornsund yearbooks [28]. Yearbooks for the 2000/01 and 2001/02 periods were subsequently published by the Institute of Geophysics, Polish Academy of Sciences [29,30]. The latest meteorological data (2003-May 2017) for PPS were derived from the OGIMET synoptic message database (http:/ / www.ogimet.com).

Meteorological phenomena, coded as current (code ' $w w^{\prime}$ ') and past (code 'WW') weather in SYNOP (surface synoptic observation) messages were used to identify days with liquid, solid, or mixed precipitation. First, using the WMO manual on codes [31], we identified and classified all precipitation events noted at observation terms as liquid ( $w w=20-21,24,25,50-59,60-67,80-82$ ), mixed $(w w=23,68,69,83,84)$, and solid ( $w w=22,26,27,70-79,85-88)$. Next, we identified a phase for past precipitation events (WW), occurring at most $3 \mathrm{~h}$ prior to observation term (W $=5$ and 6 for liquid precipitation, $\mathrm{W}=7$ for solid precipitation). The $\mathrm{W}=8$ code for past weather only indicated the occurrence of precipitation, but included no information on its phase. Therefore, $\mathrm{W}=8$ was classified from a context (similar to ww in case precipitation occurred during, before, or after observation term) or based on air temperature. The mixed precipitation group included days with sleet, as well as days with rain and snow, occurring at different times of the day. In the case of gaps in the notation of meteorological phenomena, the precipitation phase was identified based on air temperature and snow-cover data. The resulting chronological series of precipitation types for the period July 1978-May 2017 were used to present their climatology at PPS as background for further analysis. We also analyzed winter rain defined as liquid precipitation occurring between October and May in terms of its potential influence on glacier systems. Trends in winter rain occurrence and totals were calculated with Sen's slope and the linear regression (least squares) method; their statistical significance was tested using the Mann-Kendall method and t-test [32-34]. The Sen's slope and Mann-Kendall tests are non-parametric methods, i.e., no statistical distribution of data is required. However, in many studies, linear regression and t-test methods are used to analyze precipitation trends; therefore, both methods were applied in order to enable comparison with other studies.

Precipitation measurements, particularly in the Arctic, are burdened by serious errors [35-38]. To reduce measurement errors we adopted a correction factor of $15 \%$ for winter rain (originally $k l=1.15$, where $k l$ signifies the ratios between 'true' and measured liquid precipitation) recommended by [39]. This correction factor, although it did not produce a correct estimate of true liquid precipitation 
on an event-by-event basis, was used for accumulated precipitation for unsheltered stations at Spitsbergen [39].

The influence of winter rain on glacial systems was investigated for the 2009/2010-2015/2016 seasons, as determined by data availability on mass balance in Hansbreen. The beginning of the accumulation period for each glacier zone was determined using the available data (on the raising or lowering of the surface) from the SR50 ultrasonic distance meters located at various altitudes $(187,278$, and $424 \mathrm{~m}$ a.s.1.). We found that $62 \%$ of winter rain events occurred after the beginning of the accumulation period, after the snow cover formed on the glacier, which may have accumulated in the snow cover. We considered winter rain events with measurable daily totals $\geq 0.1 \mathrm{~mm}$. Trace precipitation was excluded from the analysis. Due to the lack of data on the precipitation phase directly affecting Hansbreen, we used meteorological data from PPS to identify winter rain episodes. In some cases, due to the lapse rate, air temperatures at the glacier were lower than at PPS, causing snowfall there while rain was being observed at the station. To avoid such discrepancies, we calculated lapse rates as a quotient of changes in daily air temperatures between neighboring stations (e.g., between PPS and H4, H4 and H6, or H6 and H9), and changes in elevation between these stations per $100 \mathrm{~m}$ of altitude. Using the calculated lapse rates (Equation (1)), we than calculated the air temperature for each grid over the research area. As the threshold for winter rainfall occurrence, we assumed the air temperature to be $0{ }^{\circ} \mathrm{C}$.

$$
\Delta T=\frac{d T}{d H} \cdot 100
$$

where $d T$ represents the difference in temperature, and $d H$ the difference in elevation between the upper and lower stations. Then, using the precipitation gradient from Nowak and Hodson [12], we calculated rainfall amounts for each grid based on the rainfall measured at the Polish Polar Station, using Equation (2),

$$
P R E C_{H}=P R E C_{P P S}+\left(\triangle_{P R E C} \cdot P R E C_{P P S} \cdot H\right)
$$

with the error calculated using total differential of the function:

$$
\sigma_{P R E C_{H}}=\left(\Delta_{P R E C} \cdot H+1\right) \cdot \sigma_{P R E C_{P P S}}+\Delta_{P R E C} \cdot \sigma_{H} \cdot P R E C_{P P S}
$$

where $P R E C_{P P S}$ is precipitation at PPS; $\triangle_{P R E C}$ is precipitation gradient, here $0.19 \% \mathrm{~m}^{-1}$ after [12]; $H$ is elevation; $\sigma_{H}$ is accuracy of DEM $( \pm 5 \mathrm{~m})$; and $\sigma_{P R E C_{P P S}}$ is accuracy of precipitation measurements at PPS.

The spatial distribution of air temperature over the glacier was compiled along with the spatial distribution of precipitation. Zones characterized by $\mathrm{T} \geq 0$ and PREC $\geq 0$ (PREC - precipitation, possibly in the liquid phase) were designated for the area of the glacier.

To check if the modeled precipitation is correct, each winter rain episode, identified using the modeled air temperature distribution over Hansbreen, was also compared with the data registered by the SR50 sensor. We obtained high agreement between the model and SR50 measurements (when they operated). In the case of $80 \%$ modeled precipitation they were observed on the glacier ( $55 \%$ clear liquid rainfall, and $25 \%$ liquid precipitation or ablation), while in $20 \%$ snowfall was observed (usually when the air temperature was close to $0{ }^{\circ} \mathrm{C}$ ).

In order to find the imprint of winter rain in snow cover stratigraphy, snow pits were analyzed in various glacial zones, near $\mathrm{H} 4, \mathrm{H} 6$, and $\mathrm{H} 9$, in dry snow conditions during periods of maximum snow accumulation (April-May) between 2010 and 2016. The observation method conformed to the International Commission of Snow and Ice (ICSI) classification [14]. Snowpack density was measured using Winter Engineering snow-density (area of cross section: $10.75 \mathrm{~cm}^{2}$; and tube length: $9.1 \mathrm{~cm}$ ) and snow-weight (area of cross section: $50 \mathrm{~cm}^{2}$; and tube length: $60 \mathrm{~cm}$ ) gauges.

Seasonal winter accumulation was calculated from point winter mass balance (bw) and wide-area winter mass balance (Bw) $[40,41]$ (www.wgms.ch, data from the Institute of Geophysics PAS). 
For spatial analysis of air temperature and precipitation distributions, we used a digital elevation model (DEM) with a resolution of $100 \mathrm{~m}$ horizontally and $\pm 5 \mathrm{~m}$ vertically, both estimated from Very High Resolution Satellite VHRS images from WorldView-2 (2015) [42].

\section{Winter Rainfall}

\subsection{Climatology and Changes in Winter Rain}

In the southern part of Spitsbergen, liquid precipitation is possible all year-round. Rain dominated between June and September, reaching maximum levels in July, when liquid precipitation constituted more than $90 \%$ of precipitation days and totals (Figure 2). The frequency of rain was much lower between October and May ( $7 \%$ of precipitation days). Monthly totals of rain ranged from $54.8 \mathrm{~mm}$ in September to $0.9 \mathrm{~mm}$ in March. These constituted $73 \%$ and $3 \%$ of monthly precipitation totals, respectively. However, the maximum contribution of rain to precipitation totals was found in July. The multiannual variability in monthly characteristics of precipitation phases are presented in Table 1. Although the highest monthly rain totals occurred during the summer months, episodes of winter rain were more intense. The average daily total of rain, calculated as the quotient of monthly totals and numbers of days with rain, reached an average of $3.8 \mathrm{~mm}$ between June and September, and $5.7 \mathrm{~mm}$ between October and May.

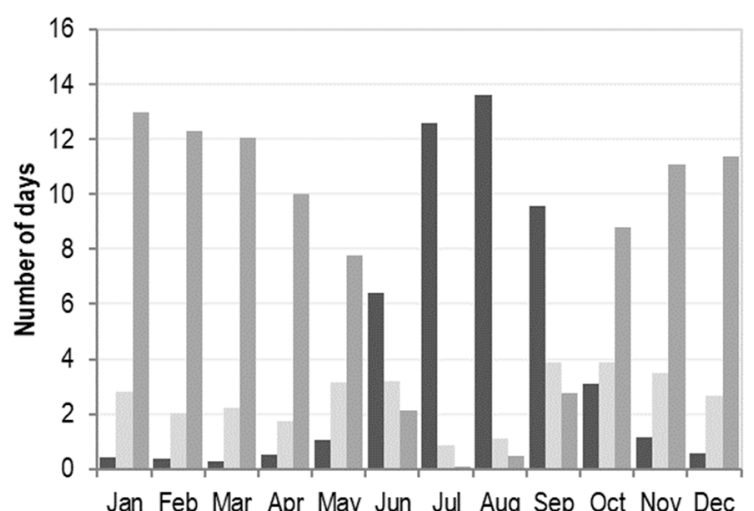

(a)

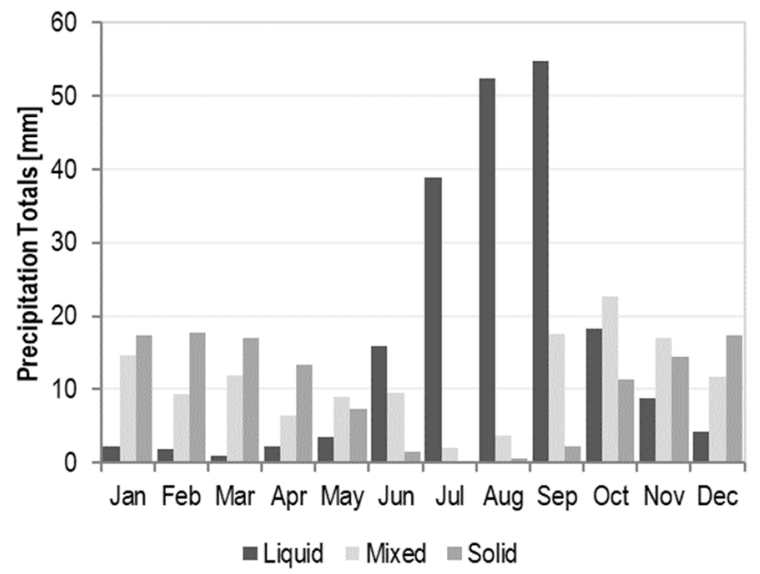

(c)

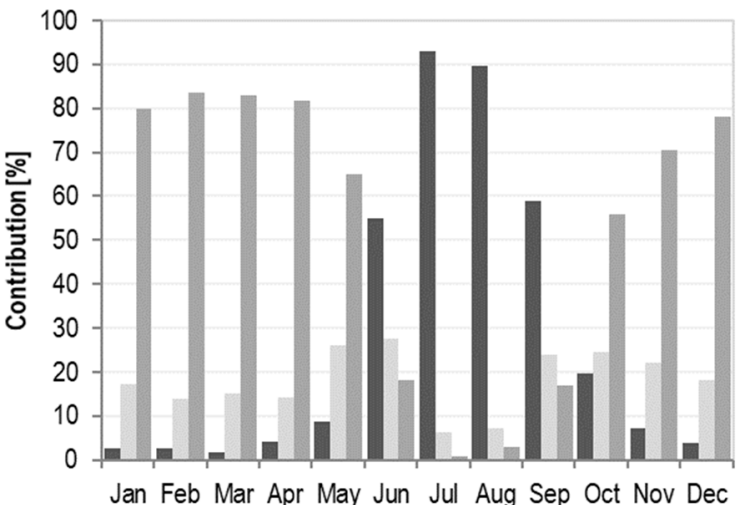

(b)

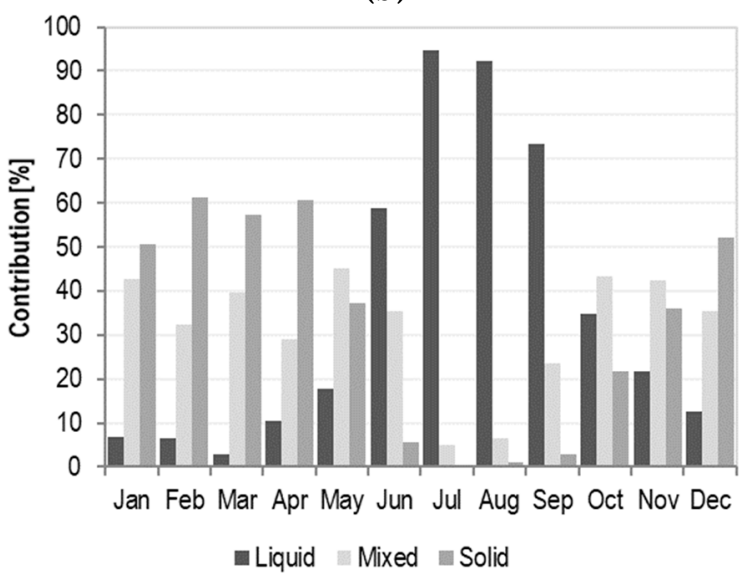

(d)

Figure 2. Annual course of liquid, solid, and mixed precipitation at Hornsund meteorological station (1979-2017): (a) number of days with precipitation, (b) contribution of precipitation forms to monthly number of days with precipitation, (c) precipitation totals, and (d) contribution of precipitation forms to monthly precipitation totals. 
Table 1. Extreme values of monthly totals and number of days with liquid, mixed, and solid precipitation in the 1979-2017 period.

\begin{tabular}{|c|c|c|c|c|c|c|c|c|c|c|c|c|}
\hline & & Jan & Feb & Mar & Apr & $\begin{array}{l}\text { Totals } \\
\text { Jun }\end{array}$ & Jul & Aug & Sep & Oct & Nov & Dec \\
\hline \multirow{2}{*}{$\mathrm{L}$} & $\max$ & 24 & 23 & 12.3 & 42.7 & 43.1 & 59.7 & 127.6 & 147.4 & 203.8 & 130.3 & 138.2 \\
\hline & $\min$ & 0 & 0 & 0 & 0 & 0 & 0 & 1.4 & 7.4 & 0 & 0 & 0 \\
\hline \multirow{2}{*}{ S } & $\max$ & 70.2 & 52.4 & 49 & 19 & 31.6 & 42.2 & 23.1 & 32.1 & 52.9 & 79.3 & 58.6 \\
\hline & $\min$ & 0 & 0 & 0 & 0 & 0 & 0 & 0 & 0 & 0 & 0 & 0 \\
\hline \multirow{2}{*}{ M } & $\max$ & 41.7 & 54.1 & 40 & 83.8 & 18.9 & 8.4 & 3.1 & 8.9 & 10.3 & 38.3 & 44.9 \\
\hline & $\min$ & 3.4 & 0.3 & 1.8 & 2.1 & 0 & 0 & 0 & 0 & 0 & 0.3 & 3.1 \\
\hline \multicolumn{13}{|c|}{ Number of Days } \\
\hline & & Jan & Feb & Mar & Apr & Jun & Jul & Aug & Sep & Oct & Nov & Dec \\
\hline \multirow{2}{*}{$\mathrm{L}$} & $\max$ & 4 & 5 & 2 & 3 & 5 & 16 & 23 & 25 & 20 & 19 & 8 \\
\hline & $\min$ & 0 & 0 & 0 & 0 & 0 & 0 & 1 & 4 & 0 & 0 & 0 \\
\hline \multirow{2}{*}{$\mathrm{S}$} & $\max$ & 12 & 12 & 8 & 7 & 9 & 9 & 4 & 6 & 10 & 9 & 12 \\
\hline & $\min$ & 0 & 0 & 0 & 0 & 0 & 0 & 0 & 0 & 0 & 0 & 0 \\
\hline \multirow{2}{*}{$\mathrm{M}$} & $\max$ & 22 & 19 & 21 & 15 & 16 & 9 & 1 & 4 & 10 & 16 & 19 \\
\hline & $\min$ & 5 & 2 & 4 & 5 & 0 & 0 & 0 & 0 & 0 & 1 & 4 \\
\hline
\end{tabular}

L, liquid; S, solid; M, mixed; max, maximum value; and min, minimum value.

In the annual course, the frequency of snowfall noticeably increased between September and October. In May the contribution of snowfall to total overall precipitation was still quite high, reaching $37 \%$, while in June it diminished to less than $6 \%$. Therefore we assumed that winter rain has the potential to influence the glacier system between October and May. However, glaciers located in the Hornsund area were characterized by a wide range of elevation, from sea level to over $500 \mathrm{~m}$ a.s.l. Due to the temperature lapse rate, the contribution of rain to total precipitation on glaciers may be lower than that noted at a meteorological station located approximately at sea level.

In most months between October and May, average liquid precipitation totals and frequencies calculated from the 2009-2017 period were higher compared to the long-term averages for 1979-2017 (Figure 3). The differences were particularly clear in October and November. In December, March, and April, differences were rather minor.

Winter rain totals and frequency in Oct-Mar have significantly increased since 2000 (Figure 4). The average total of winter rain calculated from the 2000/2001-2016/2017 seasons was $72.1 \mathrm{~mm}$, whereas it had reached $18.9 \mathrm{~mm}$ during the previous 17-year-long period, 1983/1984-1999/2000. The analogous averages for the number of days with winter rain were $12(2000 / 2001-2016 / 2017)$ and four days (1983/1984-1999/2000). Differences in the means of total and frequency of winter rain between the periods 1979/1980-1999/2000 and 2000/2001-2016/2017 were also statistically significant at $p=0.002$ for totals and $p=0.040$ for frequency, as shown by the permutation sampling method enabling the comparison of the series of various lengths [43,44]. Both parametric and non-parametric trends in the frequency of winter rain totals were positive and statistically significant. Sen's slope and the related Mann-Kendall tests indicated increases of $1.3 \mathrm{~mm}$ a year, significant at $p=0.0005$, for winter rain totals and of 0.2 day a year, significant at $p=0.0013$, for the number of days with winter rain. Trend magnitudes for the entire research period were influenced by very high values in the 2016/2017 season. In order to eliminate this effect, we also calculated trends for the period 1978/1979-2015/2016 that proved significant increase in winter rain frequency and totals (Figure 4). Part of this increase was fictitious due to the larger part of liquid phase caught by the rain gauges [45]. However, significant decrease in the annual fraction of solid precipitation, indicating rain increase was also found at other Svalbard stations and Jan Mayen $[39,45,46]$. Moreover, climate models project future dramatic increase in the entire Arctic rainfall due to melting solid precipitation driven by local air temperature trends [47]. 


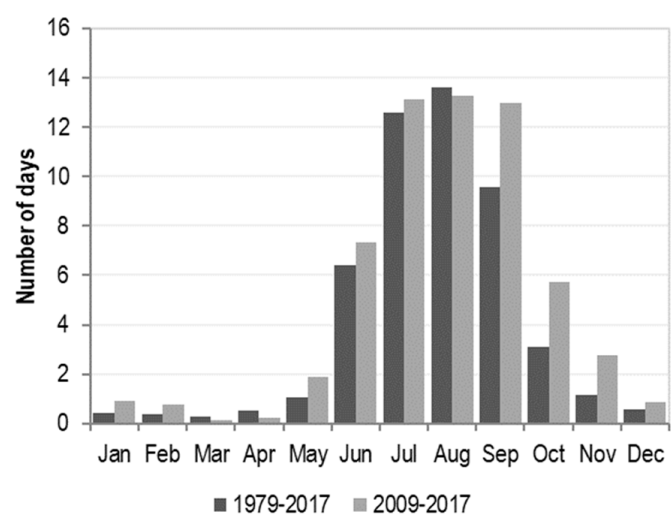

(a)

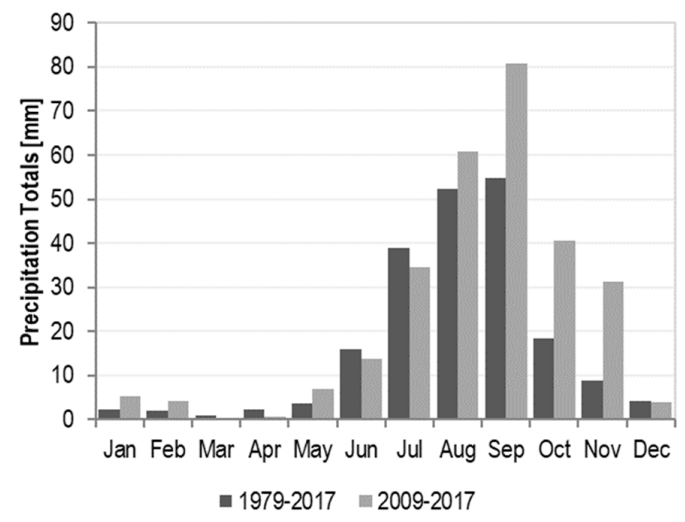

(c)

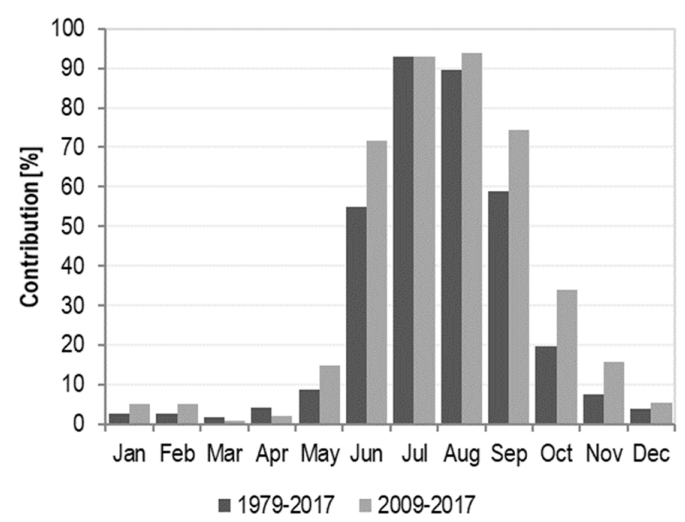

(b)

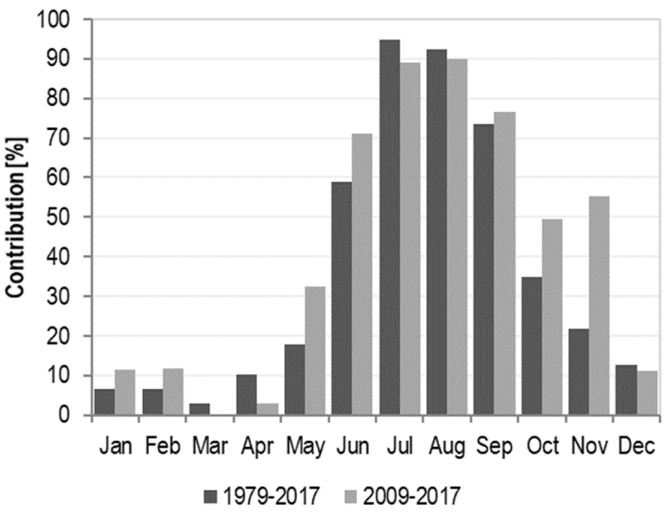

(d)

Figure 3. Monthly values of liquid precipitation characteristics in the 1979-2017 (dark bars) and 2009-2017 (light bars) periods: (a) number of days with liquid precipitation, (b) contribution of liquid precipitation to overall number of days with precipitation, (c) liquid precipitation totals, and (d) contribution of liquid precipitation to the overall precipitation totals.

\subsection{Episodes of Winter Rain in the Seasons 2009/2010 to 2016/2017}

We identified 104 days with winter rain between October and May in the seasons from 2009/2010 to $2016 / 2017$. We also examined all days with mixed precipitation to identify those with the greatest precipitation totals due to rain according to the criterion that the occurrence of snowfall may be recorded within one observational term (at most) for current weather or two observational terms for past weather. We identified 22 such days, with precipitation ranging from 1.7 to $24 \mathrm{~mm}$. Finally we selected 126 days with rain or dominant rain in the analyzed period. The seasonal (Oct-May) winter rain totals varied significantly from year to year, reaching $19 \mathrm{~mm}$ in 2012/2013 and as much as $321 \mathrm{~mm}$ in 2016/2017 (Figure 5). Implementation of the correction factor against measurement error increased the accumulated winter rain totals by $146 \mathrm{~mm}(976-1123 \mathrm{~mm})$ for the entire analyzed period.

The frequency of days with winter rain or prevailing rain (snowfall in no more than two observational terms) for daily air temperature intervals is shown in Figure 5. Daily air temperatures were re-calculated for precipitation day (from 06 to 06 UTC). Winter rain usually occurred on days with temperatures above the freezing point ( $97 \%$ of days). In only three cases was winter rain noted on days with average temperatures below $0{ }^{\circ} \mathrm{C}$. This number rises to four when days with prevailing rain are included. On most days with winter rain, air temperature over Hansbreen exceeded the freezing point, indicating precipitation in the liquid phase. On 20 days with winter rain, the average daily air temperature was below $0{ }^{\circ} \mathrm{C}$ at $\mathrm{H} 9$; however, the lower part of Hansbreen may have received rainwater (positive temperatures). On only two days were positive air temperatures recorded at PPS, while negative temperatures were recorded over Hansbreen as a whole. Thus it can be assumed that most of the winter rain identified based on PPS data also occurred in liquid form over Hansbreen. 
Of 93 such cases between 2009/2010 and 2015/2016, based on the estimated spatial distribution of air temperature and snow depth data (AWS SR50), we selected 58 winter rain events that occurred during a period of snow accumulation.

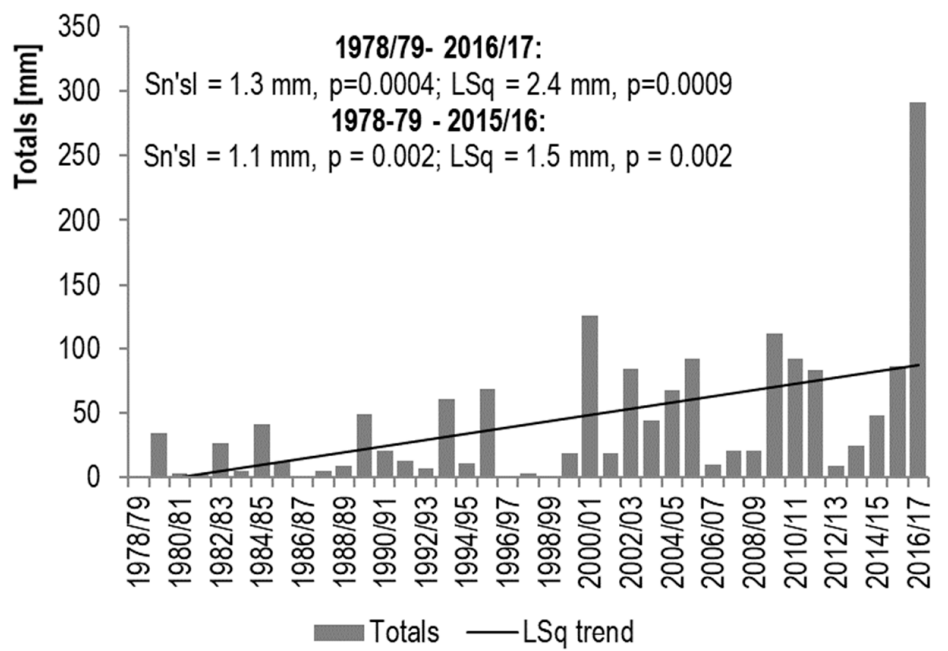

(a)

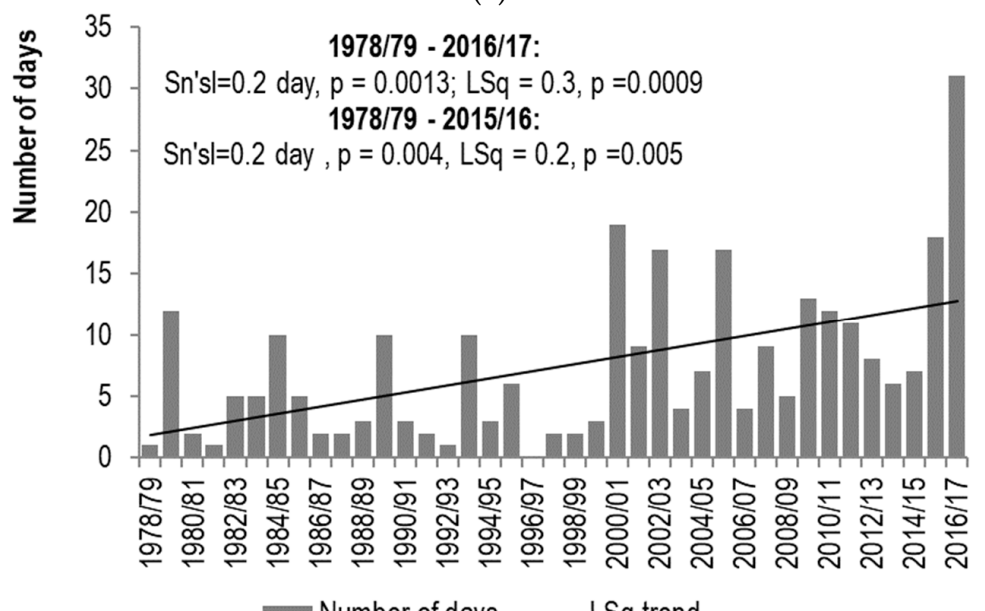

(b)

Figure 4. Long-term variability of winter rainfall totals (a) and frequency (b) in Hornsund in the period October 1978-May 2017. Winter is defined as the period between May and October. Trend magnitudes calculated with Sen's slope (Sn'sl, change per year) and linear regression of least square method (LSq, change per year), statistical significance $(p)$ checked with Mann-Kendal and t-tests, respectively.

\subsection{Examples of Acceleration of Glacier Velocity after Rainfalls}

Reaction of glacier dynamics to rainfall events differs during subsequent winters. The average surface velocity in early winter between October and December was 0.18 and $0.24 \mathrm{~m} \mathrm{day}^{-1}$ in 2014 and 2015, respectively. Some of the speed-up events before snow accumulation seasons started must have been related to rainfall, since they occurred on days with liquid precipitation or shortly afterwards. On the 4th and 5th of October 2014, following rain events with intensities of 7 and $23 \mathrm{~mm}$ per day, accordingly, the velocity of the glacier front was six times the base speed of ca $0.08 \mathrm{~m} \mathrm{day}^{-1}$ noted just before and after the speed-up event, and almost three times the base speed as of the last quarter of 2014. Prior to snow accumulation in winter 2015, two events of accelerated front movement related to liquid precipitation were recorded. The first occurred on the 11th of October, the second between the 9th and 12th November, with both reaching $0.4 \mathrm{~m}^{\text {day }}{ }^{-1}, 1.5$ times the average velocity for Oct-Dec. 
The speed-up events were linked to the intense winter rain that occurred on the 10th $(17.8 \mathrm{~mm})$ and 11th $(12.8 \mathrm{~mm}$ ) October and on 8th of November (11.9 mm) (Figure 6).

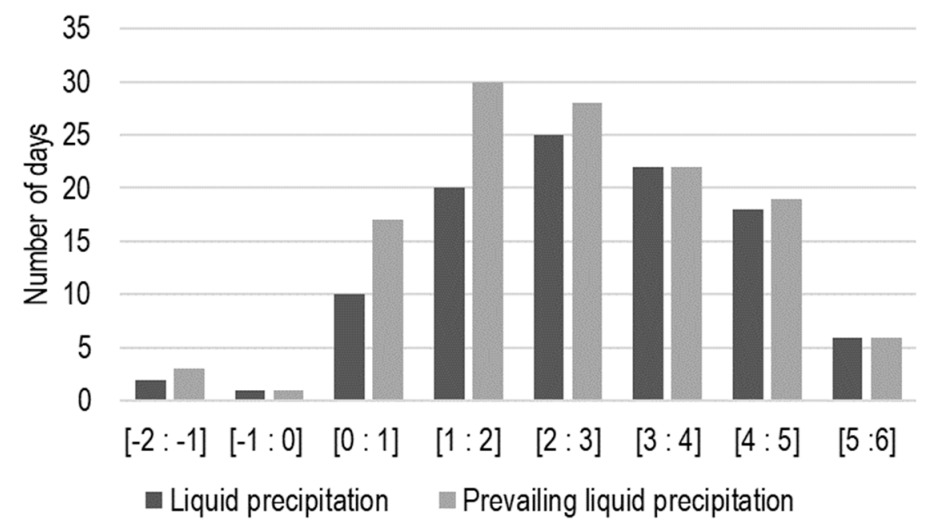

Figure 5. Frequency of winter rain (calculated from days with liquid and prevailing liquid precipitation) in air temperature intervals between 2009/2010 and 2016/2017; right-handed closed intervals.

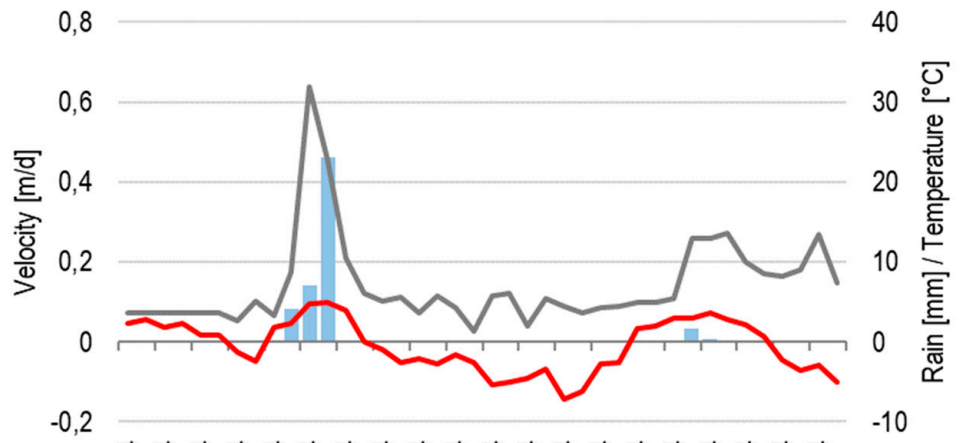

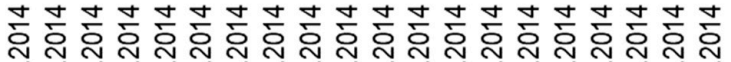

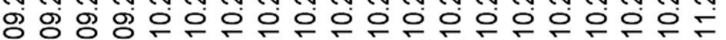

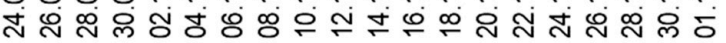

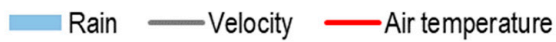

(a)

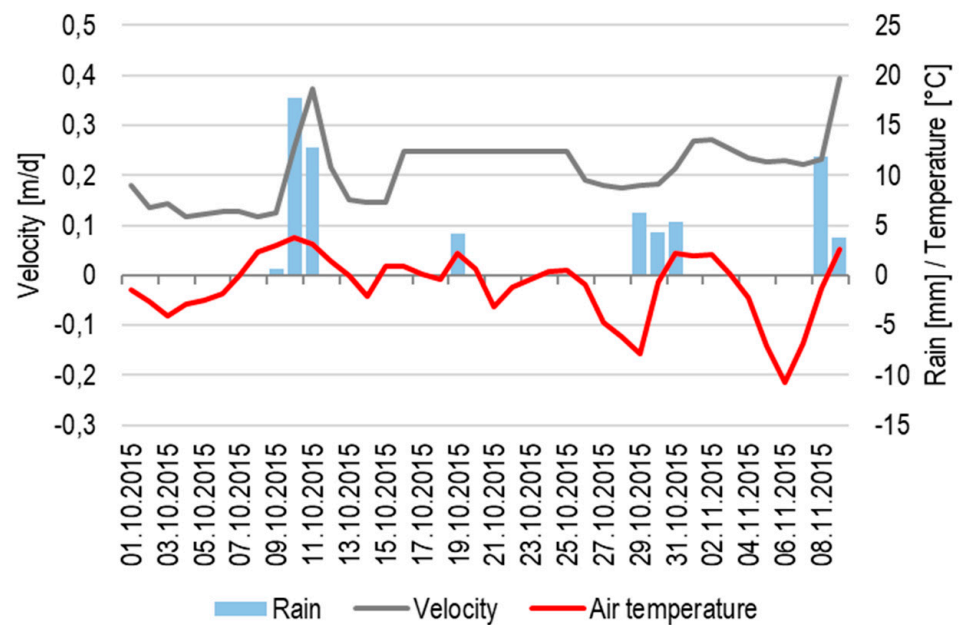

(b)

Figure 6. Average daily changes in Hansbreen velocity (grey line) from the 24th of September to 11th of November 2014 (a), and 1st of October to 11th of November 2015 (b), with clear speed-up events related to intense winter rainfall, daily totals of winter rain (06-06 UTC, blue bars), and air temperatures (red line). 
Accelerated dynamics of the Hansbreen front were also documented in mid-winter period with initially formed snow cover, due to intense rain events. Such a case was noted in January 2010. The daily average glacier velocity increased from the base level of ca 0.27 to $0.41 \mathrm{~m}^{\text {day }}{ }^{-1}$ on the 17 th of January to $0.49 \mathrm{~m} \mathrm{day}^{-1}$ on the 30th of January. Snow depth at the nearby ablation stake was ca $0.4 \mathrm{~m}$. The first speed-up event can be directly explained by heavy rain. On the 17th of January, following two days of thaw, rainfall of $20.8 \mathrm{~mm}$ was recorded at PPS. The liquid phase of this event was proven by both weather phenomena and positive air temperature (daily average $2.3^{\circ} \mathrm{C}$ ). The response of the glacier dynamics to the precipitation signal appeared quite prompt; however, in the cases discussed, snow cover had probably been filled with ablation water at an earlier point, thus the rainfall triggered rapid water drainage. The second speed-up event, in late January 2010, had no direct connection to liquid precipitation falling on the same day. However, nine days earlier (on the 22nd of January) there had been another thaw, lasting four days, ending with heavy precipitation $(22.3 \mathrm{~mm})$ on the 26th of January. Water input from this period did not affect glacier dynamics. We suppose that the waterways had previously undergone sufficient enlargement due to the water load delivered during the thaw / rain period that had occurred five days earlier. Accumulation of larger amounts of water in the subglacial system was necessary for pressure increase and acceleration of sliding. Such examples of increased glacier flow velocity after winter rain events show different dynamic reactions due to the dissimilar composition of additional factors within the glacier system.

\subsection{Traces of Rain in the Snow-Cover Structure}

Snow cover on Hansbreen exhibited considerable seasonal and spatial diversity, especially in terms of thickness. Snow depth in 2010-2016 increased by $0.62 \mathrm{~m}$ per $100 \mathrm{~m}^{-1}$ up to the region of equilibrium-line altitude, and by $1.05 \mathrm{~m}$ per $100 \mathrm{~m}^{-1}$ above ELA. The mean snow accumulation gradient between $\mathrm{H} 4$ and $\mathrm{H} 9$ was $0.88 \mathrm{~m}$ per $100 \mathrm{~m}^{-1}$. Currently, lower values of snow accumulation in comparison to historical values from the late 1980s [24] and 1990s [48] are particularly evident in higher-altitude glacial zones. During the analysis period, bulk snow density across the Hansbreen was ca $430 \mathrm{~kg} \mathrm{~m}^{-3}$, with significantly higher values compared to those of mean snow density for the glaciers of Svalbard [49], and to those from the same study area 30 years ago [50]. Increased snow density resulted particularly from winter rain-on-snow events and winter thaw periods leading to the formation of high-density layers within the snowpack. In recent years, the number of layers in the general structure of the snowpack was greater, as was also observed for other glaciers in Wedel Jarlsberg Land $[23,25]$. On Hansbreen, the contribution of the high-density layer in the snowpack structure changed gradually along with altitude, from ca $16 \%$ in the accumulation zone (H9) to ca $25 \%$ in the ablation zone (H4). The mean Snow Water Equivalent (SWE) in 2010-16 varied along the glacier from $0.61 \mathrm{~m}$ w.e. (H4) to $0.86 \mathrm{~m}$ w.e. (H6) to $1.51 \mathrm{~m}$ w.e. (H9).

\section{Estimation of the Extent of the Rain Field on Hansbreen}

Between 2009 and 2016, 93 events of winter (Oct-May) rainfall occurred on Hansbreen (Table 2). Winter rain totals varied between $28 \mathrm{~mm}$ in 2012/2013 to $295 \mathrm{~mm}$ in 2011/2012, while the frequency of rain ranged from 3 (in 2014/2015) to 21 days (in 2015/2016) (Table 2). Correlation between the totals and frequencies of winter rain events were insignificant in the analyzed period, indicating wide variation in the intensity of individual precipitation episodes.

The estimated changes in the distribution of winter rain on the surface of Hansbreen in the period of snow cover showed season-to-season variability (Figure 7). In 2009-2012, 2013/2014, and 2015/2016, winter rain covered the whole surface of the glacier, including the uppermost parts of the accumulation zone. Rainfall was the most intense in the 2009-2012 seasons, during which the average daily total ranged from 12 to $17 \mathrm{~mm}$, and seasonal totals exceeded $200 \mathrm{~mm}$. The distribution of winter rain totals on the glacier during whole winters, and of rain that fell on already-formed snow cover, accumulated over the entire study period (Figures 7 and 8). Changes in winter rain totals on the glacier, averaged over the entire research period, clearly indicated an increase in water supply in the zone between 200-300 $\mathrm{m}$ a.s.l., 
ranging from 931 to $993 \mathrm{~mm}$ (Figure 7a; grey line). However, this altitudinal distribution is strongly shaped by exceptional distribution in the $2009 / 10$ season. Excluding this particular event shifted the zone of increased water supply to $250-400 \mathrm{~m}$ a.s.l. The amounts of estimated winter rain show a negative gradient with altitude above $400 \mathrm{~m}$ a.s.l. (Figures 7 and 8). The gradient between $\mathrm{H} 4$ and $\mathrm{H} 6$ (6\% per $100 \mathrm{~m}$ ) was smaller than that between $\mathrm{H} 6$ and $\mathrm{H} 9(11 \%$ per $100 \mathrm{~m})$.

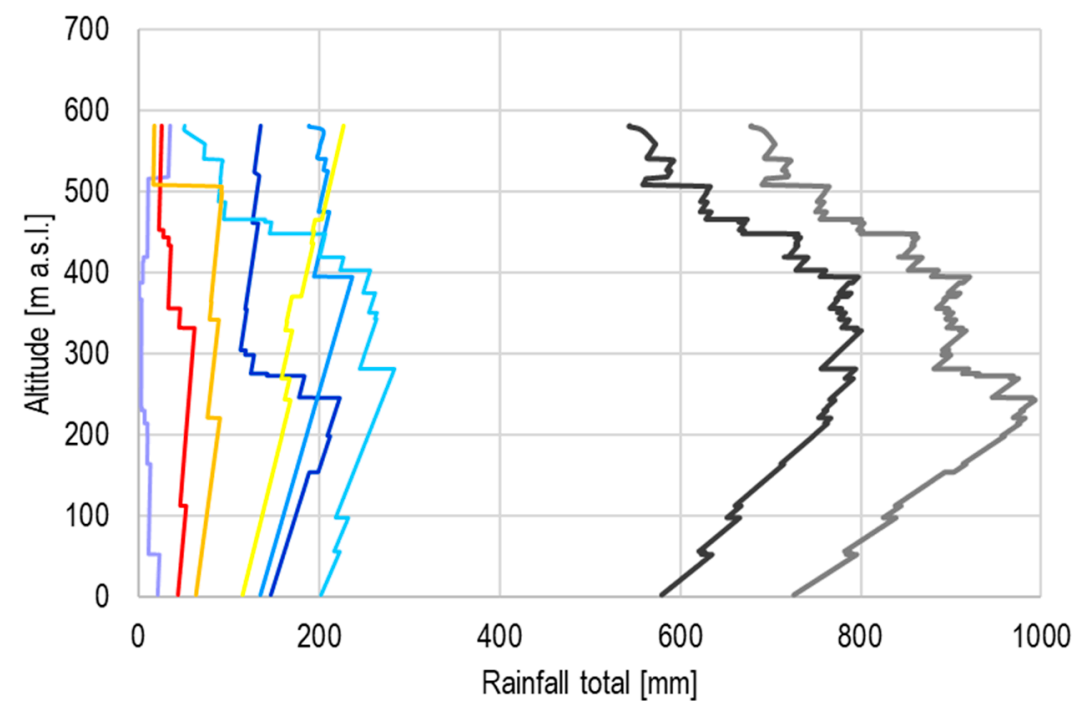

(a)

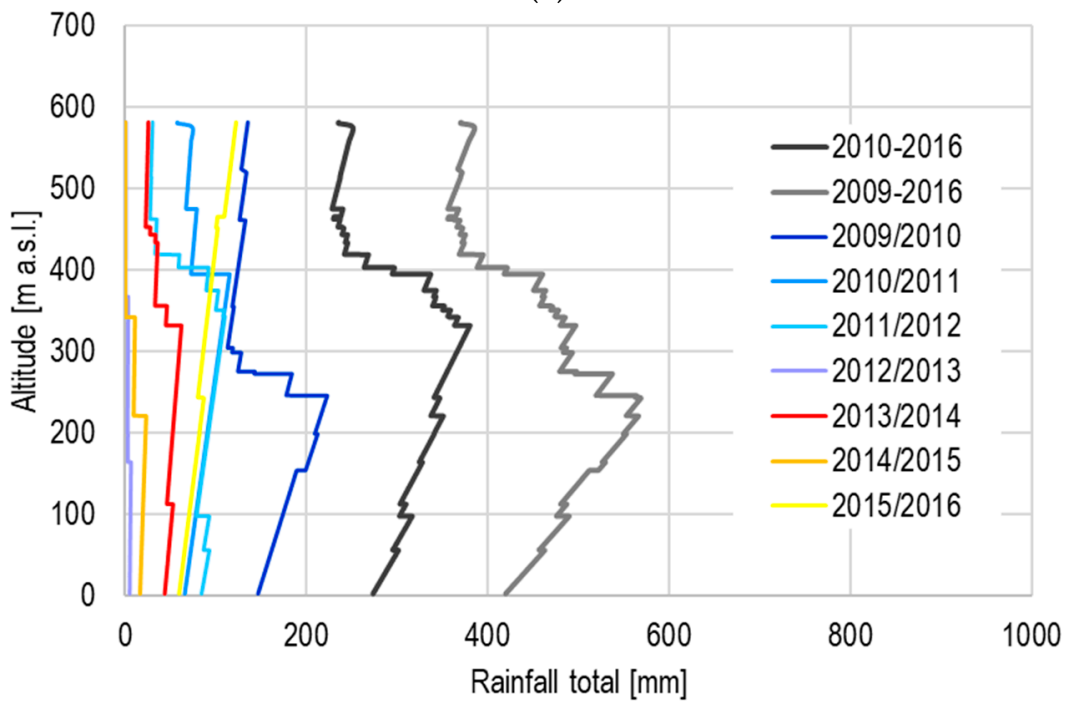

(b)

Figure 7. Changes in estimated seasonal (Oct-May) winter rain totals ( $\mathrm{mm}$ ) on Hansbreen: (a) all winter rainfall between October and May; and (b) winter rainfall occurring following snow accumulation. 


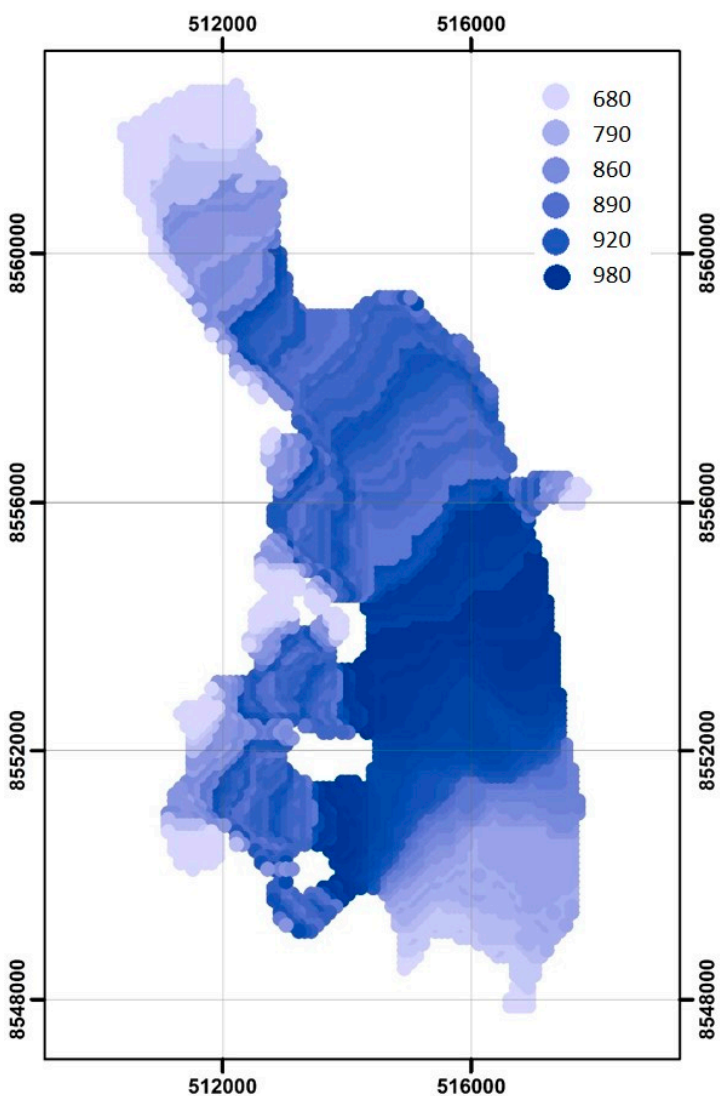

(a)

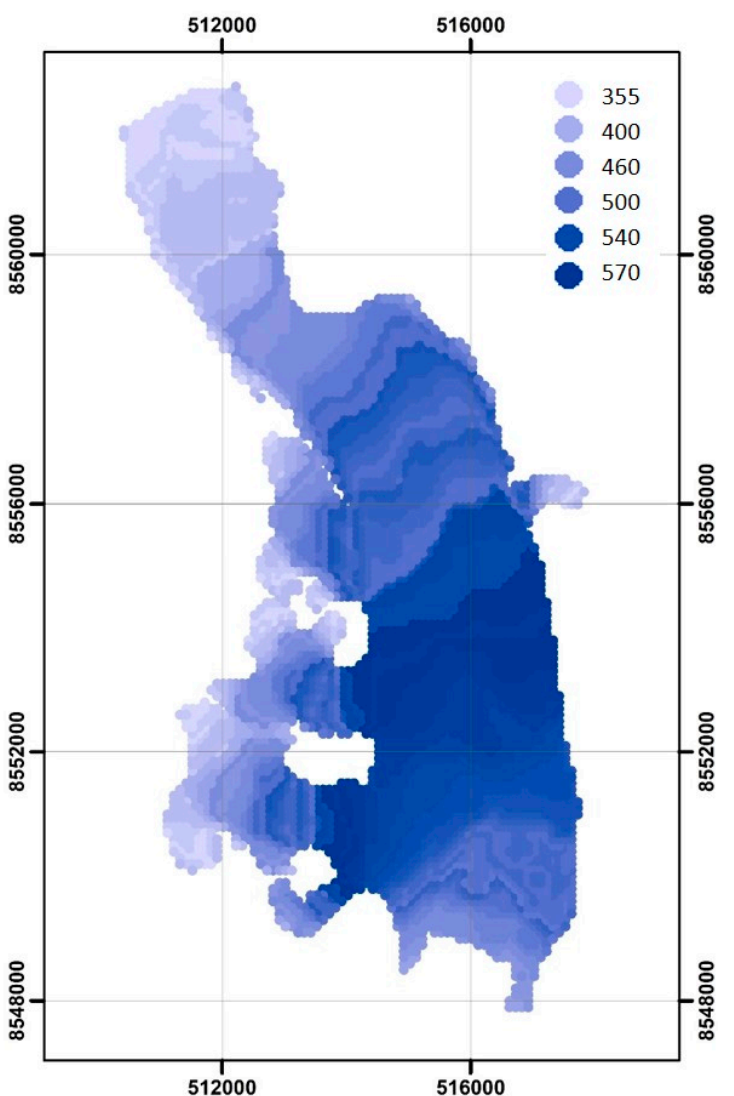

(b)

Figure 8. Spatial distribution of cumulated winter rain totals $(\mathrm{mm})$ between October and May 2009-2016 for: (a) whole period, and (b) when winter rain occurred following snow accumulation.

Table 2. Characteristics of winter rainfalls (WRs) on Hansbreen during winter (Oct-May), and during the period of snow accumulation (after snow cover forming) on the glacier.

\begin{tabular}{cccccc}
\hline $\begin{array}{c}\text { Winter } \\
\text { Seasons }\end{array}$ & $\begin{array}{c}\text { NoDWRs } \\
\text { Oct-May/Acc }\end{array}$ & $\begin{array}{c}\text { WRsT (mm) } \\
\text { Oct-May/Acc }\end{array}$ & IntWRs & AE (mm) & RE (\%) \\
\hline $2009 / 2010$ & $14 / 14$ & $221 / 221$ & $16 / 16$ & $26 / 26$ & $12 / 12$ \\
$2010 / 2011$ & $15 / 6$ & $207 / 100$ & $14 / 17$ & $27 / 10$ & $27 / 10$ \\
$2011 / 2012$ & $18 / 10$ & $295 / 119$ & $16 / 12$ & $33 / 18$ & $11 / 15$ \\
$2012 / 2013$ & $9 / 6$ & $28 / 6$ & $3 / 1$ & $13 / 6$ & $46 / 100$ \\
$2013 / 2014$ & $8 / 7$ & $61 / 51$ & $8 / 9$ & $14 / 14$ & $22 / 27$ \\
$2014 / 2015$ & $8 / 3$ & $95 / 22$ & $12 / 7$ & $15 / 5$ & $16 / 23$ \\
$2015 / 2016$ & $21 / 12$ & $177 / 91$ & $8 / 8$ & $38 / 21$ & $21 / 23$ \\
TOTAL & $93 / 58$ & $1085 / 621$ & $12 / 11$ & $166 / 100$ & $15 / 16$ \\
\hline
\end{tabular}

NoDWRs, number of days with winter rains; WRsT, winter rains totals; IntWRs, average daily intensity of winter rains; $\mathrm{AE}$, absolute error of estimation; RE, relative error of estimation calculated as a percentage of WRsT; and Acc, for the period of snow accumulation.

\section{Discussion}

As presented above, the frequency and total amount of winter rain over the last four decades have significantly increased, and their contribution to total winter precipitation in southern Spitsbergen has been substantial. This process, one of the consequences of recent climate change [45,51-58], is expected to influence glacier system functions in the High Arctic. The discussion below concerns the consequences of current winter rainfall for the selected three aspects of glacial activity: glacier mass balance, glacier dynamics, and snowpack layering as examples. 


\subsection{Contribution of Winter Rain to Glacier Mass Balance}

Glacier mass balance is defined as the difference between mass gain and loss within a specific timeframe. Arctic glaciers accumulate their mass almost entirely during the winter season. It is generally believed that the load is deposited mainly in the form of snow. However, components of mass balance include not only a solid-water phase but also liquid, vapor, and mixed phases [59]. Regardless of the phase, precipitation falling on a glacier's surface contributes to its mass balance. The capacity of the glacier to store rainfall within the glacier's body determines the impact of winter rain on the mass budget. Since glacial storage of liquid precipitation depends on both rain and the glacier's properties, several modes of rainwater flow through a polythermal glacier in wintertime are possible, depending on snow conditions:

Phase I. At the beginning of winter, before any snow cover has been formed, all liquid precipitation is quickly drained into the englacial and then into the subglacial systems. In the ablation area, the impact of rainwater on mass balance at this time is insignificant, since water is promptly drained from the glacier's surface. In the firn area, rainwater percolates through the upper layer and undergoes mid- and long-term storage in liquid and solid forms. The latter, when the cold content in the firn is sufficient for refreezing. This mechanism of internal accumulation contributes to mass gain; however, it is difficult to assess quantitatively and is not investigated in standard mass balance surveys.

Phase II. Later on, when the snow cover begins to form, it is not initially thick enough to trap and store all the rainwater, particularly in the case of intense rainfall. Part of the rainwater refreezes within the snow cover until the snowpack reaches melting-point temperatures. Low-intensity rainfall may form an icy crust on the snow's surface, effectively limiting the subsequent percolation rate. Excess water is then drained as described in Phase I.

Phase III. Once the snow cover is well developed, all rainwater is collected in the snowpack, where it refreezes. The amount of rainwater is incapable of raising the snow column's temperature to the melting point by refreezing and releasing the latent heat of fusion. It is in this step that rainwater contributes most efficiently to the winter mass balance of the glacier. Thus, we selected winter rain that occurred during snow accumulation periods with well-developed snow cover; we discuss its impact on glacier behavior below.

Phase IV. In the transition time from late winter to the ablation period, rain falls on snow cover at temperatures close to the melting point due to ablation. The contribution of meltwater and rain water to the glacier mass budget is balanced by the drainage of liquid water within the snowpack. Water is drained to the underlying layers (firn area), flows over impermeable layers, and is transferred to the rapid englacial/subglacial drainage system.

The average (2009-2016) winter mass balance of Hansbreen was $963 \mathrm{~mm}$, fluctuating between 669 and $1123 \mathrm{~mm}$ (Table 3). The mean winter mass balance (bw) calculated at H4, H6, and $\mathrm{H} 9$ exhibited a linear dependence on altitude. The increase in the winter mass balance between stakes $\mathrm{H} 4$ and $\mathrm{H} 6$ amounted to $308 \mathrm{~mm}$ per $100 \mathrm{~m}$, between stakes $\mathrm{H} 6$ and $\mathrm{H} 9$ to $304 \mathrm{~mm}$ per $100 \mathrm{~m}$. We found an increase in seasonal fluctuations of bw with altitude. The standard deviation of bw was $77 \mathrm{~mm}$ for $\mathrm{H} 4,174 \mathrm{~mm}$ for $\mathrm{H} 6$, and $254 \mathrm{~mm}$ for $\mathrm{H} 7$.

Table 3. Winter mass balance (Bw) for Hansbreen, point mass balance (bw) for H4, H6, and contribution (\%) of winter rainfalls to winter mass balance in 2009-2016.

\begin{tabular}{ccccccccc}
\hline Index & Unit & $\mathbf{2 0 0 9 / 2 0 1 0}$ & $\mathbf{2 0 1 0 / 2 0 1 1}$ & $\mathbf{2 0 1 1 / 2 0 1 2}$ & $\mathbf{2 0 1 2 / 2 0 1 3}$ & $\mathbf{2 0 1 3 / 2 0 1 4}$ & $\mathbf{2 0 1 4 / 2 0 1 5}$ & $\mathbf{2 0 1 5 / 2 0 1 6}$ \\
\hline Bw & $\mathrm{mm}$ & 1063 & 1123 & 1088 & 669 & 936 & 1002 & 857 \\
bw H4 & $\mathrm{mm}$ & 720 & 760 & 728 & 584 & 740 & 660 & 544 \\
bw H6 & $\mathrm{mm}$ & 1028 & 1250 & 968 & 644 & 940 & 1040 & 828 \\
bw H9 & $\mathrm{mm}$ & 1652 & 1700 & 1640 & 976 & 1250 & 1384 & 1208 \\
NoDWRs & days & 14 & 6 & 10 & 6 & 7 & 3 & 12 \\
BwWRs & $\%$ & 21 & 9 & 11 & 1 & 7 & 2 & 11 \\
\hline
\end{tabular}

NoDWRs, number of days with winter rains. 
In the period 2009-2016, winter rainfall in the accumulation season delivered between 6 and $221 \mathrm{~mm}$ of water to the Hansbreen's surface (with a seasonal mean of $89 \mathrm{~mm}$ ), which translated to a contribution of $9 \%$ of the winter mass balance. On a local scale, the contribution of winter mass balance can reach as high as $29 \%$ (Table 4). Minimal values of both winter rain totals and their contribution to the mass balance were obtained in 2012/2013 and 2014/2015: 6 and $22 \mathrm{~mm}$ and 1 and 2\%, respectively. These minimums were related to the low frequency of winter rain (6 and 3 days, respectively; Table 3), and the late start of the accumulation season (the beginning of November 2012 and the second part of October 2014). The maximum contribution of rainfall to the glacier mass balance reached $21 \%$ in 2009/2010, and represented the combined result of the early start of the accumulation season (17 October) and frequent winter rainfall, yielding a total of $221 \mathrm{~mm}$, the highest of the research period (Table 2).

Table 4. Contribution of winter rains to point winter mass balance in $\%$ on AWS (H4 = $187 \mathrm{~m}$ a.s.l.; $\mathrm{H} 6=278 \mathrm{~m}$ a.s.l.; and $\mathrm{H} 9=424 \mathrm{~m}$ a.s.l.).

\begin{tabular}{cccccccc}
\hline AWS & $\mathbf{2 0 0 9 / 2 0 1 0}$ & $\mathbf{2 0 1 0 / 2 0 1 1}$ & $\mathbf{2 0 1 1 / 2 0 1 2}$ & $\mathbf{2 0 1 2 / 2 0 1 3}$ & $\mathbf{2 0 1 3 / 2 0 1 4}$ & $\mathbf{2 0 1 4 / 2 0 1 5}$ & $\mathbf{2 0 1 5 / 2 0 1 6}$ \\
\hline H4 & 29 & 12 & 12 & 0 & 7 & 3 & 15 \\
H6 & 12 & 8 & 10 & 0 & 6 & 1 & 10 \\
H9 & 8 & 4 & 2 & 0 & 3 & 0 & 8 \\
\hline \multicolumn{7}{c}{ AWS, automatic weather station }
\end{tabular}

\subsection{Winter Rain and Dynamic Behavior of the Glacier}

The role of water as an agent stimulating glacier dynamics is widely acknowledged; however, this applies mostly to the meltwater produced in summertime, e.g., [60-62]. While the influence of rain on glacial movement has been acknowledged [63-65], the particular impact of winter rain has been rarely undertaken $[66,67]$.

Nearly $50 \%$ of rain events and $43 \%$ of winter rain totals recorded in winter seasons (Oct-May) during the period 2009-2016 occurred prior to the start of snow accumulation in Hansbreen. The most frequent episodes of winter rain falling on bare ice, which are the most effective in terms of glacier dynamics, occurred in 2010-2012 and 2014-2016 (Table 2). A lack of snow cover and a higher summer firm line in early winter leads to fast penetration of rainwater into the glacier's bed.

The subglacial drainage system is not efficient due to the closure of conduits by the plasticity of ice; thus even a small amount of water can significantly increase subglacial water pressure, lubricate the ice/bedrock interface, and consequently, enable more rapid movement. Similarly, substantial acceleration in glacier speed may also be observed in the initial period of snow-cover formation. On the other hand, any of the accelerated movement events recorded at Hansbreen during mid- and late-winter may have been directly related to intense rainfall. This can be explained in terms of the efficient retention properties of the snow cover, which accumulates all water from the glacier's surface or releases it gradually beneath the surface, thus preventing abrupt increases in subglacial pressure.

The influence of early winter rain on glacier dynamics seems to be similar to that observed in late summer [64,68], although liquid precipitation events are then less frequent. In winter, water is delivered to the glacier's drainage system from two sources, as rain is accompanied by winter thaws [64]; this severely limits the potential for isolating the exclusive impact of rainwater on glacier movements. Estimates for Tasman Glacier (New Zealand) show that rainfall is responsible for 11-14\% of long-term glacier displacement [65]. The retention capacities and the recent state of evolution of the glacier's drainage system may reduce the sensitivity of glacier dynamics to precipitation impulses [63]. As a consequence of the warming trend during Arctic winters, the surface coverage, altitudinal range, and seasonal totals of rain on glaciers will probably increase. Hence, since glacier dynamics are sensitive to external stimuli [64], more frequent episodes of accelerated movement of glaciers can be expected, and probably reflected in an increased annual average glacier velocity. Problem of winter 
rain episode influences on dynamics of glaciers needs additional thorough studies, especially in the context of ability to absorb rain by snow cover of different internal structure.

\subsection{Winter Rain Events Reflected in the Snowpack Structure}

Winter warm spells, which are often accompanied by rain-on-snow events, are prominent in the internal structure of the snow cover [69], serving as a significant indicator of contemporary climate change in polar regions. They can be identified even in high-elevation glacial zones [23]. Although such spells were observed in the Hornsund region in the late 1980s [24], they have become substantially more frequent in recent years, not only in the research area, but throughout the Arctic [15,25,70-74]. In southern Spitsbergen, these events are typical of the S + SWc circulation type [21], for which the greatest amounts of liquid precipitation are recorded [75]. Southern Spitsbergen, including the research area, due to its location, is particularly exposed to warm and humid air masses from the Norwegian Sea [24].

The overall contribution of the compact layers explains the increased density of the snow cover in the Hornsund region (ca $430 \mathrm{~kg} \mathrm{~m}^{-3}$ ) compared to the average for Svalbard, $370 \mathrm{~kg} \mathrm{~m}^{-3}$ [49,76], which represents partial compensation for the reduced snow depth observed in recent years; however, the overall snow water equivalent on these glaciers is still gradually decreasing, which indicates the future direction of changes in the analyzed glaciated areas.

Winter rainfall occurs mostly during thaw periods, when meltwater is produced simultaneously with winter rain. Thus all water affects the snowpack and exclusive identification of the influence of winter rain on snow structures is difficult. The study in Reference [14] specifies several snow subclasses that may be formed from both melt- and rain-water, or which may contain both types of water, including clustered rounded grains, rounded polycrystals, slush, melt-freeze crusts, ice layers, ice columns, and basal ice. Only rain crusts are exclusively formed as a result of rainfall [14]. In our study, the contribution of melt-freeze crusts and ice forms in the snow column was elaborated for the spring season in the period 2010-2016 (close to maximum accumulation) at specific sites (H4, H6, and H9). This contribution represents between $6.4 \%$ and $36.5 \%$ of the snow's thickness. The contribution of melt-freeze crusts is several times greater than that of ice forms. This means that most thaw and rain events take place on at least several days during which the top snow layer is wet, at a temperature close to melting point. Hard forms, regardless of their origin, determine the bulk density of the snowpack. The densities measured at sites $\mathrm{H} 4$ and $\mathrm{H} 9$ were closely correlated to the percentage of IF in snow thickness $(r=0.60$ and $r=0.73$, respectively), whereas the bulk density at $\mathrm{H} 6$ significantly correlated to the percentage of MFcr $(r=0.62)$. The occurrence of both classes of hard forms is interdependent, demonstrating a high correlation coefficient between the percentages of MFcr and IF at $\mathrm{H} 4$ and $\mathrm{H} 6$ ( $\mathrm{r}=0.41$ and 0.61 , respectively). At $\mathrm{H} 9$, which was characterized by the smallest contribution of hard forms to the snow's structure, no such correlation was found. As the presence of hard layers in the snowpack is a combined effect of melt- and rain-water, the statistical relationships between specific parameters of winter rainfall and MFcr/IF contribution to the snowpack are blurred. Among these ambiguous links, the significant correlation $(r=0.82)$ between percentage of IF in the snow column and contribution of winter rain to total precipitation at $\mathrm{H} 4$, appears to indicate a link between rainfall and snow structure. It can be assumed that IF was formed during effective rainfall falling on a firm cooled surface. Given its complexity, the issue of rain impact on snow structures requires further detailed investigation.

\section{Conclusions}

- The frequency of winter rainfall (Oct-May) increased in the southern part of Svalbard between 1978 and 2017, particularly in October and November.

- Data on the occurrence of winter rainfall at Polish Polar Station Hornsund proved useful for identifying the liquid precipitation phase (winter rainfall) on the glacier, provided supporting measurements on the glacier were available. 
- The contribution of rainfall to the winter mass balance of Hansbreen during the period 2009-2016 ranged from 0 to $21 \%$, with an average contribution of $9 \%$.

- The maximum total of winter rainfall and the greatest contribution of rainwater to the winter mass balance occurred on the glacier's surface area between 250-400 m a.s.l. as a combined effect of both precipitation gradient and temperature lapse rate.

- Changes in winter rainfall totals on the glacier depended on both altitude and lapse rate. The positive gradient of winter rainfall totals, due to a general altitudinal increase in precipitation rate, was found to reach the altitude of the $0{ }^{\circ} \mathrm{C}$ isotherm (ca $250-400 \mathrm{~m}$ a.s.l.). The negative gradient was found above the approximate location of the $0{ }^{\circ} \mathrm{C}$ isotherm where temperatures were more frequently below the freezing point.

- The dynamic response of the glacier to winter rainfall varied, depending on the development of both the snow cover and the glacier drainage system. Early winter rain falling on an initially thin snow cover and a drainage system, which was squeezed following large discharges (i.e., inefficient) generally resulted in increased glacier motion. On the other hand, winter rainfall occurring after the formation of a sufficiently thick snow cover was effectively stored therein and caused no significant speed-ups.

- The increased frequency of winter rainfall and thaws contributed to a greater number of hard snow layers and consequently to greater bulk density of the snowpack. As both water sources (rainfall and melting) most often occur at the same time, their individual influence on the snowpack's structure is difficult to distinguish.

Author Contributions: Conceptualization: J.J., M.G., E.B.Ł., and D.I.; methodology: E.B.Ł., D.I., and J.J.; formal analysis: E.B.Ł., D.I., K.C.-N., A.U., and B.L.; investigation: all authors; resources: D.I., M.L., T.B., and B.L.; data curation: D.I., K.C.-N., M.L., A.U., and B.L.; writing—original draft preparation: E.B.Ł., M.G., D.I., and M.L.; writing-review and editing: E.B.Ł. and K.C.-N.; visualization: E.B.Ł. and D.I.; and supervision E.B.Ł., M.G, and J.J.

Funding: This research was partly funded by: the Polish National Science Centre Grant No 2017/27/B/ST10/00923"; the funds of the Leading National Research Centre (KNOW) received by the Centre for Polar Studies of the University of Silesia, Poland and supported within statutory activities No 3841/E-41/S/2019 of the Ministry of Science and Higher Education of Poland; the European Union's Horizon 2020 research and innovation programme under grant agreement No. 727890; the Polish National Science Centre Grant DEC-2013/11/N/ST10/00823.

Acknowledgments: We would like to kindly thank the anonymous reviewers for their valuable comments that increased the scientific quality of this paper, and the Polish Polar Station in Hornsund for facilitating the data.

Conflicts of Interest: The authors declare no conflicts of interest.

\section{References}

1. Hodgkins, R. Glacier hydrology in Svalbard, Norwegian High Arctic. Quat. Sci. Rev. 1997, 16, 957-973. [CrossRef]

2. Fountain, A.G.; Walder, J.S. Water flow through temperate glaciers. Rev. Geophys. 1998, 36, $299-328$. [CrossRef]

3. Jansson, P.; Hock, R.; Schneider, T. The concept of glacier storage: A review. J. Hydrol. 2003, 282, 116-129. [CrossRef]

4. Irvine-Fynn, T.D.L.; Hodson, A.J.; Moorman, B.J.; Vatne, G.; Hubbard, A.L. Polythermal glacier hydrology: A review. Rev. Geophys. 2011, 49. [CrossRef]

5. Shreve, R.L. Movement of water in glaciers. J. Glaciol. 1972, 11, 206-214. [CrossRef]

6. Jania, J. Glacjologia. Nauka o lodowcach; PWN: Warsaw, Poland, 1997; p. 359.

7. Hagen, J.O.; Kohler, J.; Melvold, K.; Winther, J.G. Glaciers in Svalbard: Mass balance, runoff and freshwater flux. Polar Res. 2003, 22, 145-159. [CrossRef]

8. Majchrowska, E.; Ignatiuk, D.; Jania, J.; Marszałek, H.; Wasik, M. Seasonal and interannual variability in runoff from the Werenskioldbreen catchment, Spitsbergen. Pol. Polar Res. 2015, 36, 197-224. [CrossRef] 
9. Hock, R. Modelling of Glacier Melt and Discharge. Ph.D. Dissertation, Zürcher Geographische Schriften Geographisches Institut, Zürich, Switzerland, 1998; p. 130.

10. Willis, I.C. Intra-annual variations in glacier motion: A review. Prog. Phys. Geogr. 1995, 19, 61-106. [CrossRef]

11. Van Pelt, W.; Kohler, J. Modelling the long-term mass balance and firn evolution of glaciers around Kongsfjorden, Svalbard. J. Glaciol. 2015, 61, 731-744. [CrossRef]

12. Nowak, A.; Hodson, A. Hydrological response of a High-Arctic catchment to changing climate over past 35 years: A case study of Bayelva watershed, Svalbard. Polar Res. 2013, 32, 19691. [CrossRef]

13. Vikhamar-Schuler, D.; Isaksen, K.; Haugen, J.E.; Tømmervik, H.; Luks, B.; Schuler, T.V.; Bjerke, J.W. Changes in winter warming events in the Nordic Arctic Region. J. Clim. 2016, 29, 6223-6244. [CrossRef]

14. Fierz, C.; Armstrong, R.L.; Durand, Y.; Etchevers, P.; Greene, E.; Mcclung, D.M.; Nishimura, K.; Satyawali, P.K.; Sokratov, S.A. The International Classification for Seasonal Snow on the Ground; IACS Contribution N 1 ; UNESCO-IHP: Paris, France, 2009.

15. Laska, M.; Luks, B.; Budzik, T. Influence of snowpack internal structure on snow metamorphism and melting intensity on Hansbreen, Svalbard. Pol. Polar Res. 2016, 37, 193-218. [CrossRef]

16. Blatter, H.; Hutter, K. Polythermal conditions in Arctic glaciers. J. Glaciol. 1991, 37, 261-269. [CrossRef]

17. Błaszczyk, M.; Jania, J.A.; Kolondra, L. Fluctuations of tidewater glaciers in Hornsund Fiord (Southern Svalbard) since the beginning of the 20th century. Pol. Polar Res. 2013, 34, 327-352. [CrossRef]

18. Grabiec, M.; Jania, J.A.; Puczko, D.; Kolondra, L.; Budzik, T. Surface and bed morphology of Hansbreen, a tidewater glacier in Spitsbergen. Pol. Polar Res. 2012, 33, 111-138. [CrossRef]

19. Grabiec, M.; Puczko, D.; Budzik, T.; Gajek, G. Snow distribution patterns on Svalbard glaciers derived from radio-echo soundings. Pol. Polar Res. 2011, 32, 393-421. [CrossRef]

20. Grabiec, M. Stan i Wspótczesne Zmiany Systemów Lodowcowych Południowego Spitsbergenu w Świetle Badań Metodami Radarowymi; Prace Naukowe Uniwersytetu Śląkiego w Katowicach nr 3536; Wydawnictwo Uniwersytetu Śląskiego: Katowice, Poland, 2017; p. 328. ISBN 978-83-226-3015-0.

21. Niedźwiedź, T. The atmospheric circulation. In Climate and Climate Change at Hornsund, Svalbard, 2nd ed.; Marsz, A., Styszyńska, A., Eds.; Gdynia Martitime University: Gdynia, Poland, 2013; pp. 57-74.

22. Grabiec, M.; Leszkiewicz, J.; Głowacki, P.; Jania, J. Distribution of snow accumulation on some glaciers of Spitsbergen. Pol. Polar Res. 2006, 27, 309-326.

23. Laska, M.; Grabiec, M.; Ignatiuk, D.; Budzik, T. Snow deposition patterns on southern Spitsbergen glaciers, Svalbard, in relation to recent meteorological conditions and local topography. Geogr. Ann. Ser. A Phys. Geogr. 2017, 99, 262-287. [CrossRef]

24. Leszkiewicz, J.; Pulina, M. Snowfall phases in analysis of a snow cover in Hornsund, Spitsbergen. Pol. Polar Res. 1999, 20, 3-24.

25. Laska, M.; Barzycka, B.; Luks, B. Melting Characteristics of Snow Cover on Tidewater Glaciers in Hornsund Fjord, Svalbard. Water 2017b, 9, 804. [CrossRef]

26. Błaszczyk, M.; Jania, J.A.; Hagen, J.O. Tidewater glaciers of Svalbard: Recent changes and estimates of calving fluxes. Pol. Polar Res. 2009, 30, 85-142. [CrossRef]

27. Vieli, A.; Jania, J.; Blatter, H.; Funk, M. Short-term velocity variations on Hansbreen, a tidewater glacier in Spitsbergen. J. Glaciol. 2004, 50, 389-398. [CrossRef]

28. IMGW. Roczniki Meteorologiczne Hornsund (pod red. M Miętusa) 1982/1983-1999/2000; Instytut Meteorologii i Gospodarki Wodnej Oddział Morski: Gdynia, Poland, 2000-2001.

29. IG PAS. Meteorological Conditions Hornsund, Spitsbergen 2000/2001. Publ. Inst. Geophys. Pol. Acad. Sci. 2001, D-57, 3-77.

30. IG PAS. Meteorological conditions Hornsund, Spitsbergen 2001/2002. Publ. Inst. Geophys. Pol. Acad. Sci. 2003, D-60, 3-84.

31. Manual and Codes. Regional Codes and National Coding Practices; WMO-No. 306; World Meteorological Organisation: Geneva, Switzerland, 2014; p. 2.

32. Mann, H.B. Nonparametric tests against trend. Econom. J. Econom. Soc. 1945, 13, 245-259. [CrossRef]

33. Sen, P.K. Estimates of the regression coefficient based on Kendall's tau. J. Am. Stat. Assoc. 1968, 63, 1379-1389. [CrossRef]

34. Kendall, M. Multivariate Analysis; Charles Griffin \& Company: London, UK, 1975. 
35. Sevruk, B. Methods of Correction for Systematic Error in Point Precipitation Measurement for Operational Use; WMO Hydrol. Rep. 21, WMO-No. 589; World Meteorological Organisation: Geneva, Switzerland, 1982; p. 91.

36. Groisman, P.Y.; Legates, D.R. Documenting and Detecting Long-Term Precipitation Trends: Where We Are and What Should Be Done. Clim. Chang. 1995, 31, 601-622. [CrossRef]

37. Allerup, P.; Madsen, H.; Vejen, F.A. Comprehensive Model to Correcting Point Precipitation. Nord. Hydrol. 1997, 28, 1-20. [CrossRef]

38. Goodison, B.E.; Louie, P.Y.T.; Yang, D. WMO Solid Precipitation Measurement Intercomparison; World Meteorological Organization: Geneva, Switzerland, 1998; No. 872; p. 88.

39. Førland, E.J.; Hanssen-Bauer, I. Increased precipitation in the Norwegian Arctic: True or false? Clim. Chang. 2000, 46, 485-509. [CrossRef]

40. WGMS Fluctuations of Glaciers 2005-2010; ICSU(WDS)/IUGG(IACS)/UNEP/UNESCO/WMO; World Glacier Monitoring Service: Zürich, Switzerland, 2012; Volume X.

41. WGMS Global Glacier Change Bulletin No. 1 (2012-2013); ICSU(WDS)/IUGG(IACS)/UNEP/UNESCO/WMO; World Glacier Monitoring Service: Zürich, Switzerland, 2015.

42. Decaux, L.; Grabiec, M.; Ignatiuk, D.; Jania, J. Role of discrete recharge from the supraglacial drainage system for modelling of subglacial conduits pattern of Svalbard polythermal glaciers. Cryosphere 2018. [CrossRef]

43. Wise, E.K. Spatiotemporal variability of the precipitation dipole transition zone in the western United States. Geophys. Res. Lett. 2010, 37, L07706. [CrossRef]

44. Yu, Z.; Jiang, P.; Gautam, M.R.; Zhang, Y.; Acharya, K. Changes of seasonal storm properties in california and nevada from an ensemble of climate projections. J. Geophys. Res. Atmos. 2015, 120, 2676-2688. [CrossRef]

45. Førlland, E.; Hanssen-Bauer, I. Climate variations and implications for precipitation types in the Norwegian Arctic. Norw. Meteorol. Inst. Rep. 2003, 24, 21.

46. Førland, E.J.; Hanssen-Bauer, I. Past and future climate variations in the Norwegian Arctic: Overview and novel analyses. Polar Res. 2003, 22, 113-124. [CrossRef]

47. Bintanja, R.F.; Selten, M. Future increases in Arctic precipitation linked to local evaporation and sea-ice retreat. Nature 2014, 509, 479-482. [CrossRef] [PubMed]

48. Głowacki, P. Role of physical and chemical processes in the internal structure formation and mass circulation of Spitsbergen glaciers. Publ. Inst. Geophys. PAS 2007, M-30, 1-146. (In Polish)

49. Winther, J.G.; Bruland, O.; Sand, K.; Gerland, S.; Marechal, D.; Ivanov, B.; Głowacki, P.; König, M. Snow research in Svalbard-An overview. Polar Res. 2003, 22, 125-144. [CrossRef]

50. Migała, K.; Pereyma, J.; Sobik, M. Snow Accumulation in South Spitsbergen. In Wyprawy Polarne Uniwersytetu Śląskiego: 1980-1984; Uniwersytet Ślaski: Katowice, Poland, 1988; pp. 48-63.

51. Chapman, W.L.; Walsh, J.E. Recent variations of sea ice and air temperature in high latitudes. Bull. Am. Meteorol. Soc. 1993, 74, 33-47. [CrossRef]

52. Overpeck, J.; Hughen, K.; Hardy, D.; Bradley, R.; Case, R.; Douglas, M.; Finney, B.; Gajewski, K.; Jacoby, G.; Jennings, A.; et al. Arctic environmental change of the last four centuries. Science 1997, 278, 1251-1256. [CrossRef]

53. Serreze, M.C.; Walsh, J.E.; Chapin, F.S.; Osterkamp, T.; Dyurgerov, M.; Romanovsky, V.; Oechel, W.C.; Morison, J.; Zhang, T.; Barry, R.G. Observational evidence of recent change in the northern high-latitude environment. Clim. Chang. 2000, 46, 159-207. [CrossRef]

54. Førland, E.J.; Hanssen-Bauer, I.; Jónsson, T.; Kern-Hansen, C.; Nordli, P.; Tveito, O.E.; Vaarby Laursen, E. Twentieth century variations in temperature and precipitation in the Nordic Arctic. Polar Rec. 2002, 38, 203-210. [CrossRef]

55. Stieglitz, M.; Déry, S.J.; Romanovsky, V.E.; Osterkamp, T.E. The role of snow cover in the warming of Arctic permafrost. Geophys. Res. Lett. 2003, 30. [CrossRef]

56. Førland, E.J.; Benestad, R.; Hanssen-Bauer, I.; Haugen, J.E.; Skaugen, T.E. Temperature and precipitation development at Svalbard 1900-2100. Adv. Meteorol. 2011, 2011, 1-14. [CrossRef]

57. Pachauri, R.K.; Allen, M.R.; Barros, V.R.; Broome, J.; Cramer, W.; Christ, R.; Dubash, N.K. Climate Change 2014: Synthesis Report. Contribution of Working Groups I, II and III to the Fifth Assessment Report of the Intergovernmental Panel on Climate Change; IPCC: Geneva, Switzerland, 2014; p. 151.

58. Kusunoki, S.; Mizuta, R.; Hosaka, M. Future changes in precipitation intensity over the Arctic projected by a global atmospheric model with a 60-km grid size. Polar Sci. 2015, 9, 277-292. [CrossRef] 
59. Cogley, J.G.; Hock, R.; Rasmussen, L.A.; Arendt, A.A.; Bauder, A.; Braithwaite, R.J.; Jansson, P.; Kaser, G.; Möller, M.; Nicholson, L.; et al. Glossary of Glacier Mass Balance and Related Terms IHP-VII; Technical Documents in Hydrology; IACS Contribution No. 2; UNESCO-IHP: Paris, France, 2011; Volume 86.

60. Sundal, A.V.; Shepherd, A.; Nienow, P.; Hanna, E.; Palmer, S.; Huybrechts, P. Melt-induced speed-up of Greenland ice sheet offset by efficient subglacial drainage. Nature 2011, 469, 521-524. [CrossRef] [PubMed]

61. Copland, L.; Sharp, M.J.; Nienow, P.W. Links between short-term velocity variations and the subglacial hydrology of a predominantly cold polythermal glacier. J. Glaciol. 2003, 49, 337-348. [CrossRef]

62. Dunse, T.; Schuler, T.V.; Hagen, J.O.; Reijmer, C.H. Seasonal speed-up of two outlet glaciers of Austfonna, Svalbard, inferred from continuos GPS measurements. Cryosphere 2012, 6, 453-466. [CrossRef]

63. Fudge, T.J.; Harper, J.T.; Humphrey, N.F.; Pfeffer, W.T. Rapid glacier sliding, reverse ice motion and subglacial water pressure during an autumn rainstorm. Ann. Glaciol. 2009, 50, 101-108. [CrossRef]

64. Doyle, S.H.; Hubbard, A.; van de Wal, R.S.W.; Box, J.E.; van As, D.; Scharrer, K.; Meierbachtol, T.W.; Smeets, P.C.J.P.; Harper, J.T.; Johansson, E.; et al. Amplified melt and flow of the Greenland ice sheet driven by late-summer cyclonic rainfall. Nat. Geosci. 2015, 8, 647. [CrossRef]

65. Horgan, H.J.; Anderson, B.; Alley, R.B.; Chamberlain, C.J.; Dykes, R.; Kehrl, L.M.; Townend, J. Glacier velocity variability due to rain-induced sliding and cavity formation. Earth Planet. Sci. Lett. 2015, 432, $273-282$. [CrossRef]

66. Purdie, H.; Brook, M.S.; Fuller, I.C. Seasonal Variation in Ablation and Surface Velocity on a Temperate Maritime Glacier: Fox Glacier, New Zealand. Arc. Antarct. Alp. Res. 2008, 40, 140-147. [CrossRef]

67. Schellenberger, T.; Dunse, T.; Kääb, A.; Kohler, J.; Reijmer, C.H. Surface speed and frontal ablation of Kronebreen and Kongsbreen, NW Svalbard, from SAR offset tracking. Cryosphere 2015, 9, 2339-2355. [CrossRef]

68. Palmer, S.; Shepard, A.; Nienow, P.; Joughin, I. Seasonal speedup of the Greenland Ice Sheet linked to routing of surface water. Earth Planet. Sci. Lett. 2011, 302, 423-428. [CrossRef]

69. McBean, G.; Alekseev, G.; Chen, D.; Foerland, E.; Fyfe, J.; Groisman, P.Y.; King, R.; Melling, H.; Vose, R.; Whitfield, P.H. Chapter 2: Arctic Climate: Past and Present. In Arctic Climate Impact Assessment; Cambridge University Press: New York, NY, USA, 2005; pp. 22-60.

70. Ye, H.; Yang, D.; Robinson, D. Winter rain on snow and its association with air temperature in northern Eurasia. Hydrol. Process. Int. J. 2008, 22, 2728-2736. [CrossRef]

71. Westermann, S.; Boike, J.; Langer, M.; Schuler, T.V.; Etzelmüller, B. Modelling the impact of wintertime rain events on the thermal regime of permafrost. Cryosphere 2011, 5, 945-959. [CrossRef]

72. Hansen, B.B.; Isaksen, K.; Benestad, R.E.; Kohler, J.; Pedersen, Å.Ø.; Loe, L.E.; Coulson, S.J.; Larsen, J.O.; Varpe, Ø. Warmer and wetter winters: Characteristics and implications of an extreme weather event in the High Arctic. Environ. Res. Lett. 2014, 9, 114021. [CrossRef]

73. Cohen, J.; Ye, H.; Jones, J. Trends and variability in rain-on-snow events. Geophys. Res. Lett. 2015, 42, 7115-7122. [CrossRef]

74. Forbes, B.C.; Kumpula, T.; Meschtyb, N.; Laptander, R.; Macias-Fauria, M.; Zetterberg, P.; Verdonen, M.; Skarin, A.; Kim, K.Y.; Boisvert, L.N.; et al. Sea ice, rain-on-snow and tundra reindeer nomadism in Arctic Russia. Biol. Lett. 2016, 12, 20160466. [CrossRef] [PubMed]

75. Łupikasza, E.; Niedźwiedź, T.; Małarzewski, Ł. Występowanie dni z przejściem temperatury powietrza przez $0{ }^{\circ} \mathrm{C}$ na wybranych stacjach w atlantyckim sektorze Arktyki. Problemy Klimatologii Polarnej 2013, 23, 121-135. (In Polish)

76. Winther, J.G.; Bruland, O.; Sand, K.; Killingtveit, Å.; Marechal, D. Snow accumulation distribution on Spitsbergen, Svalbard, in 1997. Polar Res. 1998, 17, 155-164. [CrossRef]

(C) 2019 by the authors. Licensee MDPI, Basel, Switzerland. This article is an open access article distributed under the terms and conditions of the Creative Commons Attribution (CC BY) license (http:/ / creativecommons.org/licenses/by/4.0/). 